\title{
Labyrinthe
}

14 | 2003

Constructions de la raison

\section{L'école de Barbizon et son rayonnement}

19-20 juin 2002, université Lyon II

\section{Christian Hottin}

\section{(2) OpenEdition}

Journals

Édition électronique

URL : http://journals.openedition.org/labyrinthe/609

DOI : 10.4000/labyrinthe.609

ISSN : 1950-6031

Éditeur

Hermann

Édition imprimée

Date de publication : 1 mai 2003

Pagination : 119-121

Référence électronique

Christian Hottin, « L'école de Barbizon et son rayonnement », Labyrinthe [En ligne], 14 | 2003, mis en ligne le 11 avril 2005, consulté le 13 mai 2019. URL : http://journals.openedition.org/labyrinthe/609 ; DOI : 10.4000/labyrinthe.609

Ce document a été généré automatiquement le 13 mai 2019.

Propriété intellectuelle 


\section{L'école de Barbizon et son} rayonnement

19-20 juin 2002, université Lyon II

Christian Hottin 